\title{
The effect of the type of aggregate on the diagonal cracking of reinforced concrete beams*
}

\author{
by R. Taylor, B.Sc., D.I.C., A.M.I.C.E. and R. S. Brewer
}

\section{Contribution by W. S. Paterson, A.M.I.C.E. (John Laing Research and Development Limited)}

As I have been conducting tests of a similar nature, I was interested to read of the research work being carried out at the Building Research Station into the diagonal cracking of reinforced concrete beams, and would agree that the load factor against shear failure in beams without shear reinforcement is undesirably low. However, failures in concrete structures which could be attributed to shear are rare, if not unknown, and I would suggest that, rather than reduce the permissible stresses recommended in C.P. 114 (1957), shear reinforcement should be placed in all beams as a necessary requirement.

Would Mr Taylor and Mr Brewer agree that the higher stress at diagonal cracking for the gravel concrete beams is due to the mechanical key afforded by the aggregate when, as a general case, the crack forms round the individual pieces of aggregate, whereas the lightweight aggregate pellets themselves split under high-tensile stresses?

Similar tests carried out in our laboratories on beams without shear reinforcement, cast with a commercially available sintered pulverized fuel ash aggregrate, show close agreement with the authors' investigation. For beams with a shear span to effective depth ratio of $2 \cdot 8$, the shear stresses $(Q / b d)$ at first diagonal cracking load ranged from 110 to $147 \mathrm{lb} / \mathrm{in}^{2}$ for concrete compressive strengths of 4,000 to $6,000 \mathrm{lb} / \mathrm{in}^{2}$ respectively. One exception was a beam which failed at a stress of $110 \mathrm{lb} / \mathrm{in}^{2}$ with $7,000 \mathrm{lb} / \mathrm{in}^{2}$ concrete. In this case, the major diagonal crack did not come within the restraining influence of the vertical compression under the loading point, but reached the upper surface of the beam some inches from that point; the failure may therefore be classed as " unrestrained " as defined by Ferguson (1).

Details of beams:

$\begin{array}{ll}\text { Clear span } & 7 \mathrm{ft} \\ \text { Shear span } & 3 \mathrm{ft} 6 \text { in. } \\ \text { Effective depth } & 1 \mathrm{ft} 3 \text { in. } \\ \begin{array}{ll}\text { Reinforcement } \\ \text { (tensile only) }\end{array} & \begin{array}{l}\text { four } \frac{3}{4} \text { in. diameter hot-rolled } \\ \text { high-yield deformed bars, with } \\ \text { end hooks. }\end{array}\end{array}$

*Pages 87 to 92 of Magazine No. 44.

\section{Reply by the authors}

We thank Mr Paterson for his contribution. It is gratifying to learn that his test data for beams made with sintered p.f.a. aggregate are in close agreement with those presented in the paper.

It is difficult to follow the logic of Mr Paterson's suggestion that, since shear failures are rare, shear reinforcement should be placed in all beams rather than reduce permissible shear stresses. Nevertheless we agree that major structural members should not be built without shear reinforcement. But it will always be necessary to construct secondary members without shear reinforcement. For instance, hollow-tile floors are essentially a series of connected $T$ beams, yet it is inconceivable that for such members shear reinforcement should be sine qua non. To obtain a satisfactory safety margin for such members it is necessary to reduce the permissible stresses which are recommended in C.P. 114. The argument for a reduction has been presented previously ${ }^{(2)}$.

Incidentally shear failures are not unknown. There were the well publicized collapses ${ }^{(3,4)}$ of several warehouses in the U.S.A. There has also been a failure, unpublicized, in this country. In this case, extensive diagonal cracking in the beams of a multi-storey structure rendered the building unserviceable.

We agree with Mr Paterson that one reason for the higher diagonal cracking strengths of gravel concrete beams is the mechanical key afforded by the aggregate. (See reference 5 for further discussion of this.) This interlocking is very unreliable and is no doubt responsible for the considerable scatter of results obtained for the beams with gravel concrete.

\section{REFERENCES}

1. FERGUSON, P. M. Some implications of recent diagonal tension tests. Journal of the American Concrete Institute. Vol. 28, No. 2. August 1956.

2. TAYLOR, R. Reply to the discussion on the paper "Some shear tests on reinforced concrete beams without shear reinforcement ". Magazine of Concrete Research. Vol. 13, No. 38. July 1961 . p. 94.

3. ANDERSON, B. G. Rigid frame failures. Journal of the American Concrete Institute. Vol. 28, No. 7. January 1957. pp. 625-636.

4. ELSTNER, R. C. and HOGNESTAD, E. Laboratory investigation of rigid frame failure. Journal of the American Concrete Institute. Vol. 28, No. 7. January 1957. pp. 637-668.

5. TAYLOR, R. A note on the mechanism of diagonal cracking in reinforced concrete beams without shear reinforcement. Magazine of Concrete Research. Vol. 11, No. 33. November 1959. pp. 159-162. 